\title{
The Behavior of Dissolved Elements in the Electrolyte of the Molten Carbonate Fuel Cell
}

\author{
Hidekazu KASAI*, Yumi HAYAKAWA, Hidemi UKAI and Shiro YAJIMA
}

Received December 21, 1995 ; Accepted March 22, 1996

In a molten carbonate fuel cell, some substances deposit in an electrolyte plate during long-term operation. We have been investigating such deposits over the past few years. Major elements contained in the deposits have been identified as $\mathrm{Ni}$ and $\mathrm{Cr}$. The amounts of these elements increased with operating time. Ni dissolves from the cathode as nickel ion and is reduced to form metallic particles. On the other hand, $\mathrm{Cr}$ dissolves from the surface of cell parts such as the current collector and corrugate plate in the cathode side and deposits in an electrolyte plate as a $\mathrm{Cr}$ compound.Both substances deposit to form a layer in the electrolyte plate. The layer containing the Ni deposit and the layer containing the $\mathrm{Cr}$ compound are separated. The former layer is close to the anode in the electrolyte plate where the fuel concentration is high. Furthermore, the $\mathrm{Cr}$ compound layer is between the cathode and Ni deposit layer. From an XPS analysis, the valency of the $\mathrm{Cr}$ is different between the $\mathrm{Cr}$ compound in the electrolyte plate and that in the source materials such as $\mathrm{Cr}_{2} \mathrm{O}_{3}$ and $\mathrm{K}_{2} \mathrm{CrO}_{4}$. It is considered that the $\mathrm{Cr}$ compound dissolving in the electrolyte plate is reduced and deposits as different chromate salts. According to the long term operation and the deposition mechanisms, it is estimated that these depositions are not limited in amount.

\section{INTRODUCTION}

The stability of the components in a molten carbonate fuel cell (MCFC) is the most important parameter for achieving long cell life. After more than ten thousand hours of operation, some substances significantly dissolve into the electrolyte plate which causes loss of cell performance.

For example, $\mathrm{NiO}$, which is the standard material of an MCFC cathode, dissolves in the electrolyte plate as nickel ion and deposits as metal particles. The micro and macro structures of the cathode change and the cathode's performance then deteriorates. Furthermore, it is thought that Ni particles form an electrical shunt between the anode and the cathode. This shunt causes electrical shorting.

Ishikawajima-Harima Heavy Industry Co., Ltd.

(1-15, Toyosu 3-Chome, Koto-KU, Tokyo, 135, Japan)

Key words : Molten carbonate fuel cell, Nickel, Chrome, doposition,
This phenomenon has been reported 1,2).

We have been analyzing the components of an MCFC after long-term operation. For almost all cases, $\mathrm{Ni}$ and $\mathrm{Cr}$ have been identified in addition to the initial elements in the electrolyte plate. The amount of these elements increases with operation time. Furthermore, the deposition state changes with the cell operating conditions such as temperature and gas composition.

We reported 3,4 ) the behavior of $\mathrm{Ni}$ deposition in the electrolyte plate. However, the behavior of the deposition compound containing $\mathrm{Cr}$ has not yet been reported and has not yet been discussed. In this paper, we describe the states of the compounds containing $\mathrm{Cr}$ in the electrolyte plate and the correspondence between $\mathrm{Ni}$ and the compound containing $\mathrm{Cr}$ upon the deposition in the electrolyte plate.

\section{EXPERIMENTAL AND ANALYSES}

2.1 Cell components The molten carbonate 
fuel cell consists of an anode, a cathode, an electrolyte plate and a separator or a holder. Both electrodes have a porous structure for the electrochemical reaction. The separator or holder has two roles. The first one is to distribute fuel gas and oxidization gas to each cell. The second one is to conduct electrical current. The schematic cross section of the MCFC is shown in Fig. 1.

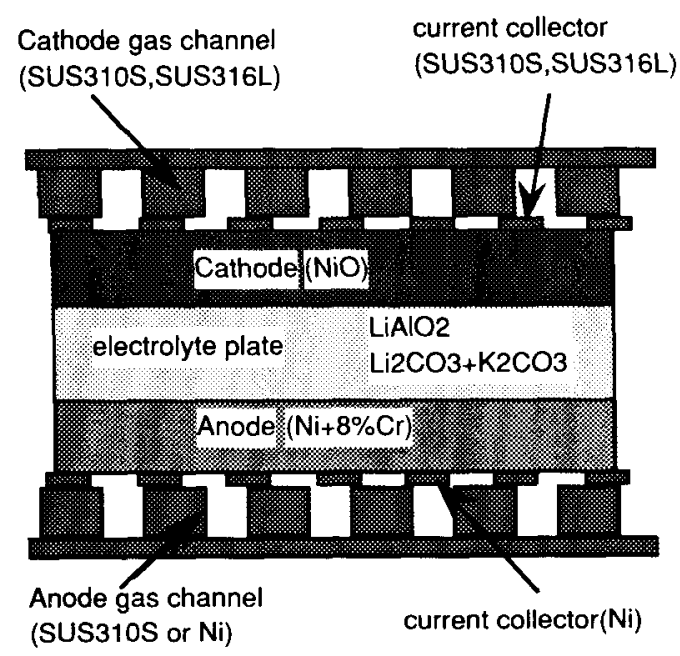

Fig.1 Schematic cross section at view of a cell .

From the point of view of materials, the cathode is made of nickel oxide and the anode is made of $\mathrm{Ni}-8 \% \mathrm{Cr}$ alloy. The electrolyte plate is made of lithium aluminate and a carbonate mixture. The holder and the separator are mainly made from stainless steel such as SUS310S and SUS316L. Ni is partially used for the active area in the separator where the fuel gas flows and electrical current flows.

The specifications of the cell components are shown in Table 1. The electrode area of the cells change from $100 \mathrm{~cm}^{2}$ to $1 \mathrm{~m}^{2}$.

2.2 Cell operation The operating conditions of the cell are shown in Table 2 . In the case of a small cell, temperature is nearly uniform across the cell. On the other hand, in the case of a large size cell, temperature is not uniform in the cell. The operating temperature ranges from $863 \mathrm{~K}$ to $1023 \mathrm{~K}$ in the case of a bench scale cell test. As usual in a large size cell, temperature in the gas inlet side of the cell is controlled within $830 \mathrm{~K}$ to $860 \mathrm{~K}$ while the temperature in the gas outlet side of a cell is controlled within $930 \mathrm{~K}$ to $960 \mathrm{~K}$.

\begin{tabular}{|c|c|c|c|}
\hline component & material & $\begin{array}{l}\text { thickness } \\
(\mathrm{mm})\end{array}$ & $\begin{array}{c}\text { porosity } \\
(\%)\end{array}$ \\
\hline $\begin{array}{l}\text { holder } \\
\text { separator }\end{array}$ & $\begin{array}{l}\text { SUS310S or SUS } \\
\mathrm{Ni} \text { or SUS310S }\end{array}$ & S316L & \\
\hline anode & $\mathrm{Ni}+8 \% \mathrm{Cr}$ & $0.7 \sim 0.8$ & $50 \sim 60$ \\
\hline $\begin{array}{l}\text { electrolyte } \\
\text { plate }\end{array}$ & $\begin{array}{l}\mathrm{LiAlO} 2 \\
+\mathrm{Li}_{2} \mathrm{CO}_{3} / \mathrm{K}_{2} \mathrm{CO}_{3} \\
(62 / 38 \text { or } 70 / 30)\end{array}$ & $0.9 \sim 1.1$ & $55 \sim 60$ \\
\hline cathode & $\mathrm{NiO}$ (in-situ type) & $0.7 \sim 0.8$ & $60 \sim 70$ \\
\hline
\end{tabular}

Table 2 Operating conditions of a cell

$\begin{array}{ll}\text { anode gas } & \mathrm{H}_{2} / \mathrm{CO}_{2} / \mathrm{H}_{2} \mathrm{O}=67 / 17 / 17 \\ \text { cathode gas } & \mathrm{Air} / \mathrm{CO}_{2}=70 / 30 \\ \text { temperature } & 590^{\circ} \mathrm{C} \sim 750^{\circ} \mathrm{C} \\ \text { current density } & 150 \mathrm{~mA} / \mathrm{cm}^{2}\end{array}$

The gas flow configuration is a co-flow type. The longest operating time of such cells is over 20000 hours. The operation pressure is usually kept constant and ranges from $1 \mathrm{~atm}$ to $5 \mathrm{~atm}$.

2.3 Analysis methods $\mathrm{The} \mathrm{Ni}$ and $\mathrm{Cr}$ concentrations in the electrolyte plate were measured by atomic absorption analysis. A cross section of the electrolyte plate was observed using a microscope and was analyzed by EPMA. Surfaces of the separator and holder were analyzed using the $\mathrm{X}$-ray diffraction method. 
In order to analyze the surface of the cell components, we used two types of XPS (ESCA). One (SHIMAZU ESCA650B) analyzes a wide surface area of a sample at one time: The other analyzes a spot surface of a sample and can move the measurement spot. Both analyzers use $\mathrm{Mg}$-Ka as the X-ray source and can clean the sample surface using Aretching.

\section{RESULTS AND DISCUSSION}

\subsection{Amount of $\mathrm{Ni}$ and $\mathrm{Cr}$ in the} electrolyte

3.1.1 Effect of operating time $T$ he amount of nickel and chrome increases with the operating time as shown in Fig. 2 and Fig. 3. These increasing curve were found not to be linear with time. According to the results obtained after a long operating time, the amounts of both depositions were considered not to attain saturation.

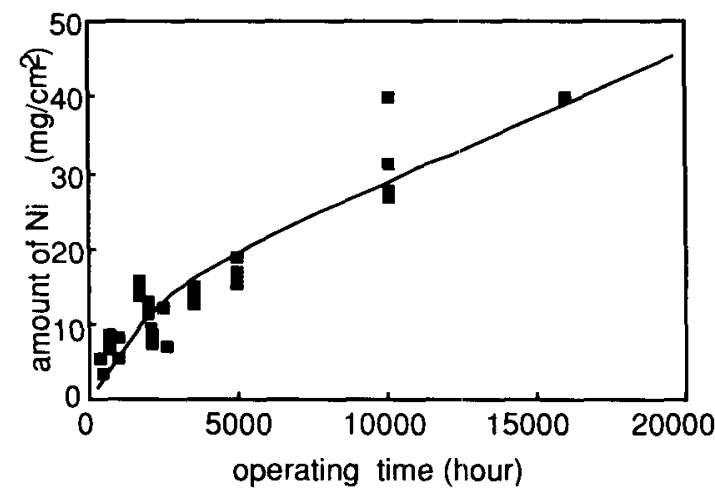

Fig.2 Change of the Ni amount with time

\subsubsection{Effect of temperature The effect of} temperature on the amounts of $\mathrm{Ni}$ and $\mathrm{Cr}$ deposits are different. From the investigation of the effect of operating cell temperature, the amount of $\mathrm{Ni}$ deposition decreases with an increase in cell temperature while the amount of $\mathrm{Cr}$ compound increases with an increase in cell temperature as shown in Fig. 4.

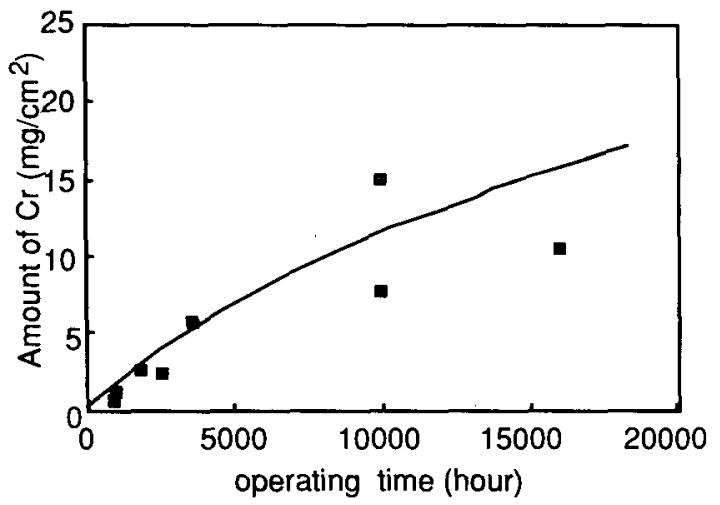

Fig. 3 Change of the $\mathrm{Cr}$ amount with time

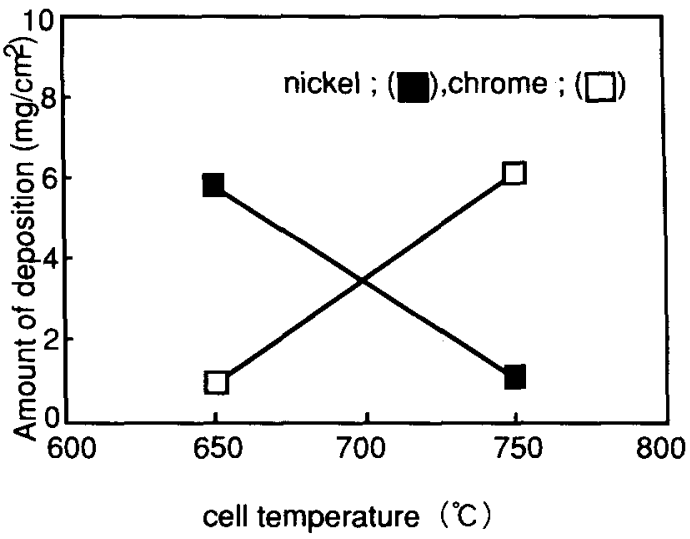

Fig.4 Change of the amount of deposition in the electrolyte with temperature after 500 hours operation at $100 \mathrm{~cm}$ cell.

The dissolution rate of a cathode is considered to change with the concentration of $\mathrm{Ni}^{2+}$ ion in the carbonate mixture. The relationship between cell operating temperature and the amounts of $\mathrm{Ni}$ deposition is considered to be due to the equilibrium solubility of $\mathrm{NiO}$, which decreases with an increase temperature in the carbonate mixture ${ }^{5,6)}$.

The solubility of $\mathrm{Cr}_{2} \mathrm{O}_{3}$ in the carbonate increases with an increase in temperature. The dependence of the amount of deposited $\mathrm{Cr}$ compounds is considered to be due to this solubility behavior. 


\subsection{State of deposits}

3.2.1 Figure of deposits The optical micro graph of a typical cross section of the cell is shown in Fig. 5. A layered structure parallel to the electrode appeared in the electrolyte plate. A yellow or brown layer was observed near the cathode. Next to this layer, we found a layer of metallic particles. From EPMA measurements, it was determined that the yellow or brown layer contains $\mathrm{Cr}$ and the metal particles are made of $\mathrm{Ni}$. The distribution of $\mathrm{Ni}, \mathrm{Cr}$ and $\mathrm{Al}$ in the electrolyte plate was determined by the scanning EPMA measurement as shown in Fig. 6.

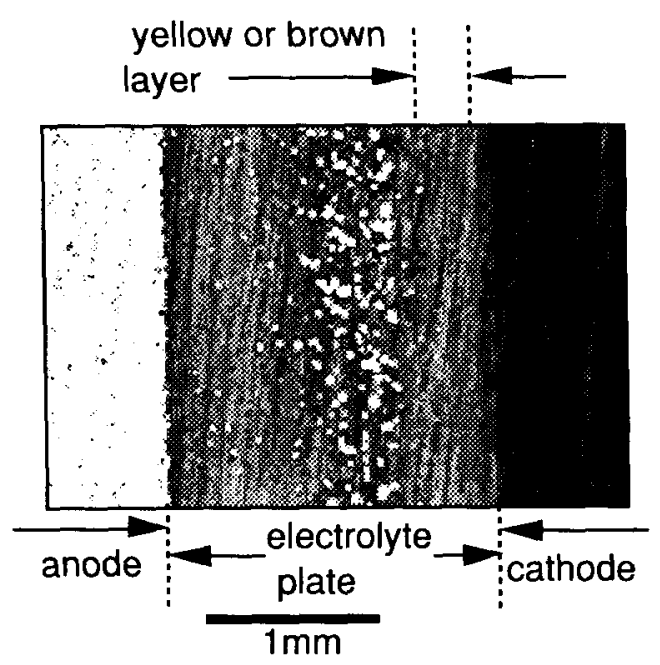

Fig.5 Optical microphotograph of the electrolyte plate cross section after testing

The distributions of $\mathrm{Ni}$ and $\mathrm{Cr}$ are distinctive. Considering the solubility of $\mathrm{Ni}$ in the carbonate mixture, it is thought that almost all $\mathrm{Ni}$ in the electrolyte plate forms metallic particles. On the other hand, the $\mathrm{Cr}$ compound forming particles were not observed using the optical microscope. The diameter of the Ni particles was mainly several tens of using micron, and large grains containing several particles were recognized.

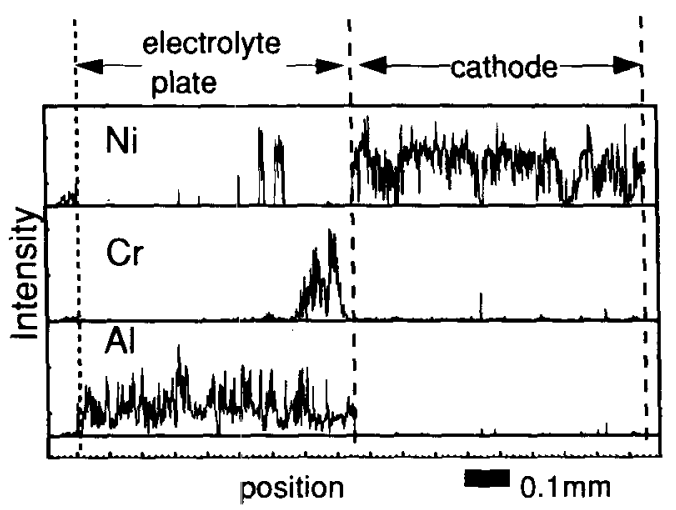

Fig. 6 Result of EPMA at the cross section of the electrolyte plate

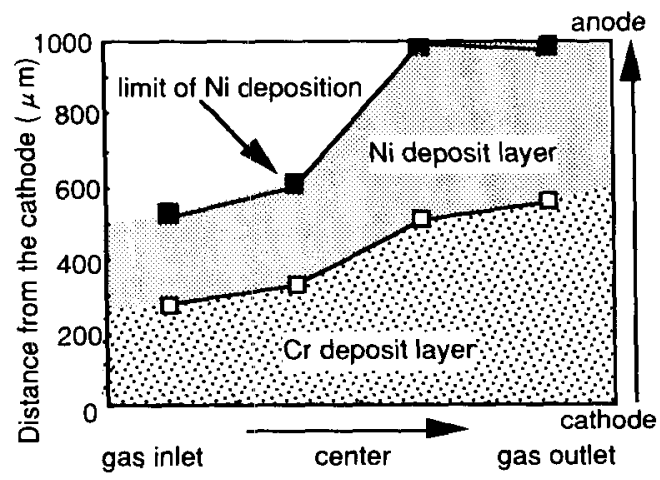

Fig.7 Location and outline of the deposition layers in the electrolyte plate obtained from the result of EPMA. Cross sectional view along a gas flow. Limit of $\mathrm{Ni}$ deposit; ( $\square$ ), and order between $\mathrm{Ni}$ and $\mathrm{Cr} ;(\square)$ )

\subsubsection{Position of deposit layer $\mathrm{T} h \mathrm{e}$} positions and thickness of these layers in the electrolyte plate are not similar in the cell. We observed these layers along the electrolyte plate using EPMA. The schematic diagram of the cross sectional layer structure state in the electrolyte plate is shown in Fig. 7.

For the area near the gas inlet, the layer containing nickel particles is far from the anode and particles are scattered in a narrow region. On the other hand, in the area near the gas outlet, the laver of nickel particles is close to the 
anode, and particles are scattered over a wide region. This distribution of $\mathrm{Ni}$ particles have been usually observed in other cells regardless of cell size.

The concentration of $\mathrm{H}_{2}$ in the fuel gas is lower at the outlet than at the inlet because of the consumption of $\mathrm{H}_{2}$ during the anode reaction. Also, the change in the concentration of oxidative gas is similar. A reductive-oxidative potential in the electrolyte plate is considered to change both with the $\mathrm{H}_{2}$ concentration and oxidative gas concentration.

It is considered that the appearance of the layer containing $\mathrm{Ni}$ particles corresponds to the reduction potential and its gradient in the electrolyte plate and the amount of $\mathrm{Ni}$ deposit is proportional to the amount of dissolved $\mathrm{Ni}$ ion. Furthermore, the Ni dissolution rate is affected by the $\mathrm{CO}_{2}$ partial pressure in the cathode gas.

According to the above mentioned scheme, the reductive and oxidative potentials in the layer containing the $\mathrm{Cr}$ compound is considered to be located in the more oxidative atmosphere than the layer containing the $\mathrm{Ni}$ deposit.

The appearance of both the $\mathrm{Ni}$ deposit layer and the layer containing the $\mathrm{Cr}$ compound deposits are schematically shown in Fig. 7.

\subsection{Result of XPS}

\subsubsection{Measurement of XPS In order to} identify the $\mathrm{Cr}$ compound, we use two types of XPS as mentioned in the following paragraph. Because the samples have a rough surface and are covered with carbonate, we treated these surfaces with Ar-etching from 20 minutes to 120 minutes to make the XPS peak of $\mathrm{Cr}$ distinctive and to stabilize its position among the spectra. However, the binding energy values of the $\mathrm{Cr} 2 \mathrm{p} 2 / 3$ peak identified in the spectra using two XPS systems are different. One reason for this effect is the charging on the sample's surface.

Because there is much noise in both spectra, the Cr2p2/3 peaks could not been treated for peak resolution by curve fitting. It appears that each peak consists of a single peak.

3.3.2 Wide area measurement A sample of the electrolyte plate attached to the anode was divided in the middle of the electrolyte plate as shown in Fig. 8. The two surfaces were measured by XPS. One is the anode and the other is that of the dividing interface.

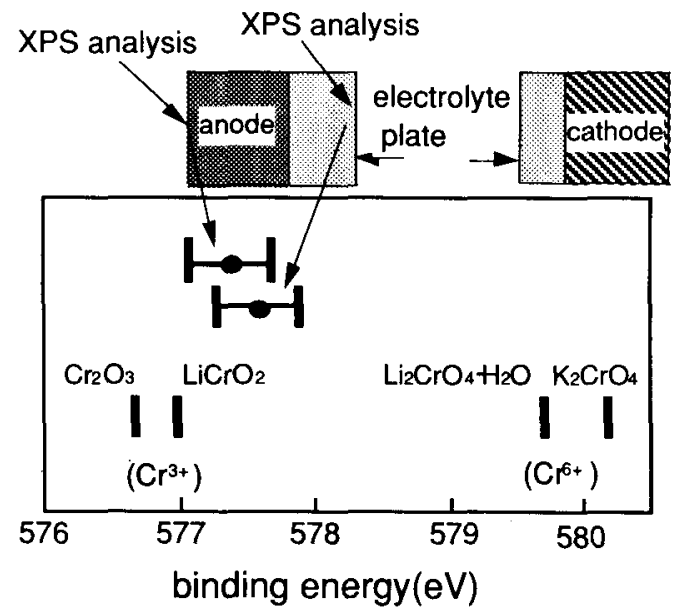

Fig. 8 Value of $\mathrm{Cr} 2 \mathrm{p} 2 / 3$ peak of the $\mathrm{Cr}$ compound from XPS (wide area) and values of the reference samples in the literature

From the results of elemental analysis and Xray diffraction, $\mathrm{Cr}$ compounds identified on the cell parts of the cathode side are $\mathrm{Cr}_{2} \mathrm{O}_{3}$ and $\mathrm{K}_{2} \mathrm{CrO}_{4}$. Also, it was identified the $\mathrm{Cr}$ compounds in the anode are $\mathrm{LiCrO}_{2}$ and $\mathrm{Cr}_{2} \mathrm{O}_{3}$. $\mathrm{LiCrO}_{2}$ is formed by the reaction of $\mathrm{Cr}_{2} \mathrm{O}_{3}$ and $\mathrm{Li}_{2} \mathrm{CO}_{3}$. The XPS peak of the $\mathrm{Cr}$ compound from the surface of the anode is estimated to be that of $\mathrm{LiCrO}_{2}$ because all the $\mathrm{Cr}_{2} \mathrm{O}_{3}$ on the surface reacts with $\mathrm{Li}_{2} \mathrm{CO}_{3}$ to form $\mathrm{LiCrO}_{2}$. 
The binding energy value of the $\mathrm{Cr} 2 \mathrm{p} 2 / 3$ peak identified from XPS of the anode agrees with that for $\mathrm{LiCrO}_{2}$ in the literature ${ }^{4)}$. There is about a $3 \mathrm{eV}$ gap between the $\mathrm{Cr} 2 \mathrm{p} 2 / 3$ peak of $\mathrm{K}_{2} \mathrm{CrO}_{4}\left(\mathrm{Cr}^{+6}\right)$ and $\mathrm{LiCrO}_{2}\left(\mathrm{Cr}^{+3}\right)$ in the same report. As for the XPS data obtained from the dividing interface, the binding energy value of the $\mathrm{Cr} 2 \mathrm{p} 2 / 3$ peak is close to that of $\mathrm{LiCrO}_{2}$. However, it is slightly bigger than that identified for the anode surface. The relation of these binding energy values are shown in Fig. 8.

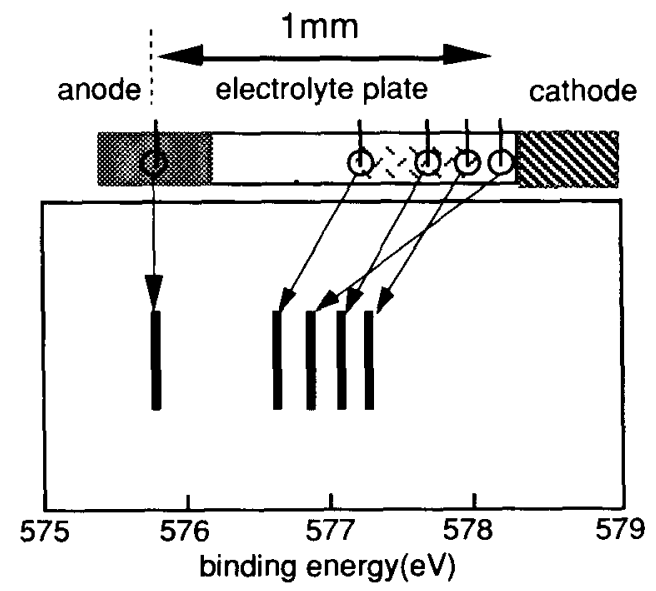

Fig. 9 Value of $\mathrm{Cr} 2 \mathrm{p} 2 / 3$ peaks at several positions in the electrolyte plate from XPS (spot).

\subsubsection{Spot measurement XPS spot} measurements were done on the cross section of the cell as shown in Fig. 9. The binding energy of the $\mathrm{Cr} 2 \mathrm{p} 2 / 3$ peak changes within about a $1.5 \mathrm{eV}$ difference. The binding energy values of the $\mathrm{Cr}$ peak from the electrolyte plate are lower than the that from anode which is about $576 \mathrm{eV}$. This difference is similar to the result observed using the wide area XPS as mentioned in the previous section. These binding energy values were obviously different from that for $\mathrm{K}_{2} \mathrm{CrO}_{4}$.

\subsection{Mechanism of deposition}

3.4.1 Nickel particles The source of $\mathrm{Ni}$ is mainly the $\mathrm{NiO}$ of the cathode. $\mathrm{NiO}$ dissolves in the carbonate as $\mathrm{Ni}^{2+}$ ion. This process is explained as follows. ${ }^{8)}$

$$
\mathrm{NiO}+\mathrm{CO}_{2} \rightarrow \mathrm{Ni}^{2+}+\mathrm{CO}_{3}^{2-}
$$

The dissolving nickel ion diffuses from the cathode to the anode in the electrolyte, and is reduced as metallic particle by hydrogen that diffuse from the anode.

$$
\mathrm{Ni}^{2+}+\mathrm{H}_{2}+\mathrm{CO}_{3}^{2+}->\mathrm{Ni}+\mathrm{H}_{2} \mathrm{O}+\mathrm{CO}_{2}
$$

3.4.2 Chrome compounds It is clear that the source of $\mathrm{Cr}$ is mainly the corrosion layer of the parts on the cathode side such as the current collector. From the post-test analysis, the $\mathrm{Cr}$ content of the anode does not change and from the mass balance of $\mathrm{Cr}$ among the anode, the cathode and the electrolyte plate, the total amount of $\mathrm{Cr}$ exceeds that of the initial value. The surface of the stainless steel used for the cathode side parts are covered with a chrome oxide film $\left(\mathrm{Cr}_{2} \mathrm{O}_{3}\right)$. This oxide reacts with carbonate and form $\mathrm{M}_{2} \mathrm{CrO}_{4}(\mathrm{M}=\mathrm{Li}, \mathrm{K})$ under the cathode gas conditions. The reaction is as follows.

$\mathrm{Cr}_{2} \mathrm{O}_{3}+2 \mathrm{M}_{2} \mathrm{CO}_{3}+3 / 2 \mathrm{O}_{2}->2 \mathrm{M}_{2} \mathrm{CrO}_{4}+2 \mathrm{CO}_{2}$

Also chromate ion might be reduced by hydrogen that diffuses from the anode.

According to Hsu's phase diagram ${ }^{9}$ ) for chromate-carbonate, it is considered that $\mathbf{M}$ is mainly $\mathrm{K}$ under the cathode gas conditions. From our analytical results, almost all chromate compounds on the active area of the cathode side parts were recognized to be $\mathrm{K}_{2} \mathrm{CrO}_{4}$. This chromate dissolves into the carbonate through 
the cathode and diffuses from the cathode to the anode. Along with this diffusion, the valence of chrome might change from $\mathrm{Cr}^{6+}$ to $\mathrm{Cr}^{3+}$ in the electrolyte plate, because the equilibrium partial pressure of $\mathrm{O}_{2}$ in the electrolyte plate decreases as it approaches the anode. According to Hsu's phase diagram, under the cathode gas conditions, $\mathrm{K}_{2} \mathrm{CrO}_{4}$ is stable, and under the anode gas conditions, $\mathrm{LiCrO}_{2}$ is stable.

The $\mathrm{Cr}$ compound forming layer in the electrolyte plate is not still identified. This compound obviously differs from $\mathrm{K}_{2} \mathrm{CrO}_{4}$.

\section{CONCLUSIONS}

Two elements, $\mathrm{Ni}$ and $\mathrm{Cr}$, accumulate in the electrolyte plate of a molten carbonate fuel cell during its long-term cell operation. $\mathrm{Ni}$ deposition and $\mathrm{Cr}$ compound deposition form a layer in the electrolyte. The two layers are separate on the electrolyte plate. The location and the outline of the two layers in the electrolyte plate reflect the reductive and oxidative atmospheres in the electrolyte plate.

The $\mathrm{Cr}$ compound-forming layer in the electrolyte plate has not been identified. The valency of $\mathrm{Cr}$ differs from 6 or 3 based on an XPS analysis.

The protection of the dissolution of the cell components and the deposition in the electrolyte plate are an important concern for making a long life cell. It is necessary to clarify these phenomenona for the commercialization of a molten carbonate fuel cell.

This work has been conducted under a contract from NEDO (New Energy and Industrial Technology Development Organization) and MCFC Research Association (Technology Research Association for Molten
Fuel Cell Power Generation System) as part of the New Sunshine Program of MTTI (Ministry of Industrial Trade and Industry). We appreciate their advice and support.

\section{REFERENCES}

1) H.R.Kunts and J.W.Pandolfo, $J$. Electrochem. Soc., 139, 1549 (1992).

2) Y.Mugikura, T.Abe, S.Yoshioka and H. Urushibata,J.Electrochem.Soc.,142,2971 (1995).

3) H.Kasai, A.Suzuki and S.Sato, NIKKA, 8, 1345(1988).

4) H.Kasai and A.Suzuki, Proc.THIRD INTERNATIONAL SYMPOSIUM ON CARBNATE FUELCELL TECHNOLOGY, 1993, ISBN 1-56677-072-6.

5) K.Ota, T.Shinjo and N. Kamiya, Denki Kagaku, 55, 327(1987).

6) K.Ota and N.Kamiya, J.Electrochem.Soc., 139, 667 (1992), March 1992.

7) J.F.Moulder, W.F.Stickle, P.E.Sobol, K.D.Bomben, "Handbook of X-ray

Photoelectron Spectroscopy", PerkinElmer(1992).

8) C.E.Baumgartner, J. Am. Ceram. Soc., 69, 162 (1986).

9) H.S.Hsu, J.H.DeVan, and M.Howell, J.Electrochem.Soc.: Electrochemical Science and Technology 134, 2146 (1987). 